\title{
Faktor-Faktor yang Mempengaruhi Minat Beli Produk Makanan Olahan Halal pada Konsumen
}

\author{
Saniatun Nurhasanah \\ Sekolah Pascasarjana Departemen Manajemen, Fakultas Ekonomi dan Manajemen \\ Institut Pertanian Bogor \\ Email: sunny_hasanah@yahoo.com \\ Jono M Munandar* \\ Sekolah Pascasarjana Departemen Manajemen, Fakultas Ekonomi dan Manajemen \\ Institut Pertanian Bogor \\ E-mail: jonomun@gmail.com

\section{Muhammad Syamsun} \\ Sekolah Pascasarjana Departemen Manajemen, Fakultas Ekonomi dan Manajemen \\ Institut Pertanian Bogor
}

\begin{abstract}
Indonesia is one of the largest Moslem population countries in the world. It leads to the increasing of halal product demand in Indonesia. The awareness to consume halal product becomes a large market potential for producers to produce their halal products. Nowadays, halal is not only purely about religion matter, but also about business and trade. The objective of this study is to investigate the factors affecting customers on purchasing halal buying interest on processed food. We use a purposive sampling method with 109 respondents who are customers of the supermarkets and minimarkets in Bogor City/District, Indonesia. While data analysis is done by SEM-PLS method, this study uses brand image, perceived quality, perceived value, halal certification, health reason, halal awareness, and halal marketing as the factors which are affecting the halal purchase intention of the customers. The result showed that health reason, halal awareness, and perceived value have a significant and positive direct effect on purchasing intention. Halal marketing also shows a significant and positive effect on purchasing intention. While halal marketing shows a negative and significant effect on purchasing intention. The food safety, halal certification, brand image, and perceived quality show the same effect which has no direct effect on purchasing intention. Furthermore, food safety has an indirect effect on purchasing intention through health reason. Halal certification has an indirect effect on minat beli through brand image variable. Meanwhile, brand image and perceived quality have an indirect effect through perceived value variable on purchasing intention.
\end{abstract}

Keywords: halal food, buying interest, Structural Equation Modeling

\begin{abstract}
ABSTRAK
Indonesia adalah salah satu negara dengan populasi Muslim terbesar di dunia. Hal ini menyebabkan meningkatnya permintaan produk halal di Indonesia. Kesadaran untuk mengkonsumsi produk halal menjadi potensi pasar yang besar bagi produsen untuk memproduksi produk halal mereka. Saat ini, halal tidak hanya murni soal agama, tapi juga soal bisnis dan perdagangan. Tujuan dari penelitian ini adalah untuk mengetahui faktor-faktor yang mempengaruhi minat pelanggan dalam membeli pada makanan olahan halal. Kami menggunakan metode voluntery sampling dengan 109 responden yang merupakan pelanggan supermarket dan minimarket di Kota/Kabupaten Bogor, Indonesia. Sedangkan analisis data dilakukan dengan metode SEM-PLS. Penelitian ini menggunakan citra merek, persepsi kualitas, persepsi nilai, sertifikasi halal, kesehatan, kesadaran halal, dan Pemasaran halal sebagai faktor yang mempengaruhi niat pembelian halal pelanggan. Hasil penelitian menunjukkan bahwa kesadaran halal, alasan kesehatan, dan persepsi nilai berpengaruh positif dan signifikan terhadap
\end{abstract}

*Corresponding author 
niat beli. Pemasaran halal juga menunjukkan efek positif dan signifikan terhadap niat beli. Sedangkan pemasaran halal menunjukkan efek negatif dan signifikan terhadap niat beli. Keamanan pangan, sertifikasi halal, citra merek, dan kualitas yang dirasakan menunjukkan efek yang sama yang tidak berpengaruh langsung pada niat beli. Selanjutnya, keamanan pangan berpengaruh tidak langsung terhadap niat beli melalui alasan kesehatan. Sertifikasi halal memiliki efek tidak langsung terhadap niat beli melalui variabel citra merek. Sedangkan citra merek dan persepsi kualitasmemiliki pengaruh tidak langsung melalui persepsi nilai variable terhadap niat beli.

Kata kunci: makanan halal, minat beli, Structural Equation Modeling

\section{Pendahuluan}

Produk halal mengacu pada produk-produk yang memenuhi syarat syar'i yang mencegah keharaman, baik ditinjau dari segi zatnya maupun selain zatnya (Burhanuddin 2011). Menurut Al-Ghazali (2007), yang mengakibatkan makanan (benda) bisa menjadi haram karena jenisnya yang haram, seperti khamar, babi, dan sebagainya, termasuk di dalamnya produk-produk dari turunannya (alkohol, gelatin, dan lainnya), dan haram karena cara memperolehnya yang termasuk di dalamnya adalah harta untuk memperolehnya dan proses membuatnya. Murujuk data PT sofyan Hospitality International, pada tahun 2016, tingkat konsumsi muslim di tingkat tingkat global sebesar US\$ 1.8 triliun, sementara di Indonesia mencapai US\$ 225.7 miliar. Dalam lima tahun terakhir, pertumbuhan industry yang mengusung konsep halal di Indonesia mencapai $40 \%$, yang terdiri dari pakaian, makanan, hotol, kosmetik, dan syariah finansial (Mix 2017). Lembaga Pengkajian Pangan, Obat-obatan, dan Kosmetik Majelis Ulama Indonesia (LPPOM MUI) sebagai satu-satunya lembaga yang berwenang dalam memberikan sertifikat halal sampai tahun 2014 sebanyak 26979 dari jumlah 8636 perusahaan dengan jumlah produk yang sudah disertifikasi halal sebanyak 53383 dari 231851 produk yang beredar (Kementrian Agama 2015).

Menurut Badan Pusat Statistik (BPS) jumlah penduduk muslim Indonesia mencapai 207 juta muslim atau 87.18\% dari penduduk Indonesia (BPS 2010). Sehingga dengan pangsa pasar produk halal sebesar itu tentu kebutuhan produk halal di pasar menjadi sangat besar. Berdasarkan survei yang dilakukan oleh tim riset Majlis Ulama Indonesia (MUI) terungkap bahwa tingkat kesadaran masyarakat Indonesia akan produk halal meningkat sangat signifikan. Jika pada tahun 2009 tingkat kepedulian masyarakat terhadap kehalalan produk hanya berkisar 70\%, pada akhir 2010 angka tersebut melonjak menjadi sekitar 92.2\%, yang artinya seharusnya potensi ini bisa menjadikan Indonesia sebagai produsen halal tingkat dunia (Syahruddin 2014). Meningkatnya kesadaran umat Islam di seluruh dunia pada kewajiban mereka untuk mengkonsumsi makanan yang memenuhi persyaratan pola konsumsi Islam telah menciptakan permintaan yang lebih besar untuk halal makanan dan produk (Ambali dan Bakar 2013).

Pemerintah Kota Bogor mencanangkan Program Kota Bogor Menuju Kota Halal (BSN 2014). Adapun pengertian Kota Halal dimaksud adalah tidak mengharuskan seluruh produk makanan yang dijajakan halal, tetapi harus ada kejelasan produk makanan yang benar-benar halal dengan adanya tanda yang jelas sehingga memudahkan masyarakat untuk mengenalinya. Bogor sebagai kota Halal diwujudkan agar masyarakat dan wisatawan yang ke Bogor (khususnya yang beragama islam) bisa 
mendapatkan haknya untuk dapat mengkonsumsi makanan halal dan thayyib tanpa keraguan pada produk yang dihasilkan ataupun dijajakan ataupun dimasukkan ke Bogor karena informasi yang benar dan akurat, yaitu sudah dilakukan tindakan preventif dan kontrol terhadap produk sehingga memenuhi produk ASUH (aman, sehat, utuh dan halal) bagi konsumen. Kabupaten dan Kota Bogor merupakan daerah padat penduduk dengan jumlah muslim terbanyak di Jawa Barat, yaitu mencapai 96.67\% dari total penduduknya (BPS 2010). Banyaknya penduduk beragama Islam di Kota Bogor diharapkan akan meningkatkan kesadaran penduduk untuk mengetahui pentingnya mengonsumsi pangan halal sehingga dapat meningkatkan minat beli makanan halal dan ikut mendorong program Bogor Kota Halal.

Pada masa kini, halal tidak lagi murni sebagai isu agama, tetapi juga masuk dalam ranah bisnis dan perdangan (Borzooei and Asgari 2013). Halal dapat menjadi faktor pembeda dan dengan mencari, menyoroti dan mengkomunikasikan sertifikasi Halal mungkin dapat memperluas ke pasar dunia (Rajagopal et al 2011). Perdagangan makanan halal telah meningkat pesat sementara semakin banyak negara telah mengadopsi Islamic Finance dalam sistem perbankan mereka (Ahmad 2014). Manfaat dari produk halal berpengaruh pada sikap dan perilaku konsumen dalam hal niat untuk membeli produk dan mereka bersedia membayar untuk produk halal (Aziz dan Chok 2013). Sebaliknya, perusahaan yang mengacuhkan isu halal ini akan ditinggalkan oleh konsumennya.

Penelitian tentang minat beli halal benar-benar mencakup area pertimbangan yang luas: kesadaran halal (Qaradhawi 2013, Aziz dan Chok 2013, Apriyantono 2005), persepsi nilai (Apriyantono 2005), sertifikasi halal (Aziz dan Chok 2013, Apriyantono 2005, Husain et al 2016), keamanan pangan (Husain et al 2016), persepsi nilai (Wang dan Tsai 2014, Husain et al 2016), citra merek (Wang dan Tsai 2014), kesehatan (Husain et al 2016).

Berdasarkan latar belakang penelitian di atas, maka rumusan permasalahan dalam penelitian ini adalah : (1) Bagaimana pengaruh faktor-faktor yang meliputi citra merek, persepsi kualitas, persepsi nilai, sertifikasi halal, kesehatan, kesadaran halal, dan pemasaran halal terhadap minat beli produk makanan halal? (2) Bagaimana pengaruh variabel keamanan pangan terhadap kesehatan? (3) Bagaimana pengaruh variabel pemasaran halal dan sertifikasi halal produk terhadap citra merek produk makanan halal? (4) Bagaimana pengaruh citra merek produk terhadap persepsi kualitas dan persepsi nilai produk makanan halal?

\section{Metode Penelitian}

Objek penelitian ini adalah konsumen yang membeli produk makanan olahan pada swalayan dan minimarket di wilayah Kota/Kabupaten Bogor. Metode pengambilan sampel yang digunakan dalam penelitian ini adalah non-probability sampling dengan menggunakan teknik purposive sampling (Cooper dan Emory 1997). Pengambilan sampel berdasarkan kriteria tertentu, dimana responden adalah konsumen yang membeli produk makanan olahan yang dipasarkan pada hypermarket, supermarket, dan mini market yang berdomisili di Kota dan Kabupaten Bogor. Penelitian dilakukan selama satu bulan dengan menggunakan kuisioner kepada responden secara langsung serta menyebarkan kuisioner secara secara langsung kepada responden dan secara online melalui aplikasi 
google form yang disebar melalui media sosial. Pada kuisioner, skala yang digunakan adalah skala likert berdasarkan tingkat kesetujuan responden pada setiap indikator (1-6).

Metode analisis data yang digunakan dalam penelitian ini menggunakan analisis deskriptif untuk indentifikasi karakteristik dan metode analisis Structural Equation Modeling (SEM) dengan software SmartPLS 3.2.6. Structural Equation Modeling (SEM) erupakan suatu teknik analisis multivariate generesi kedua yang menghubungkan antara analisis faktor dan analisis jalur sehingga memungkinkan peneliti menguji dan mengestimasi secara simultan hubungan antara multiple exogenous dan endogenous variable dengan banyak faktor (Latan 2013). Analisis dalam model SEM dapat dibagi menjadi dua tahapan yaitu model pengukuran dan analisis struktural model. Tujuan melakukan model pengukuran yaitu untuk mengetahui seberapa kuat variabel manifes menggambarkan setiap variabel laten eksogen dan endogen. Setiap variabel laten memiliki beberapa variabel manifest (indikator) yang reflektif terhadap setiap variabel latennya. Indikator-indikator tersebut diperoleh dari studi pustaka.

Tahapan analisis dengan menggunakan metode SEM ini yang pertama adalah membuat analisis path diagram untuk menginterpretasikan hubungan antara variabel laten dan indikator pada software PLS. Kemudian dilakukan analisis model pengukuran (measurement model) untuk dilihat nilai outer loading untuk mengevaluasi hubungan anatar variabel konstruk dengan indikator manifesnya. Kemudian dilanjukan dengan analisis structural (inner model) dengan melihat nilai bootstrapping untuk menilai hasil estimasi parameter path coefficiency dan tingkat signifikansinya.

Analisis model pengukuran atau outer model dilakukan melalui analisis konfirmatori dengan uji konvergen (convergent validity), dan uji reliabilitas (composite reliability) (Mulyono 2016). Menurut Asyraf (2013), Nilai indikator ini dapat diterima saat nilai outer loading 0,50 atau lebih tinggi untuk mempertahankan model pengukuran. Selain nilai outer loading, model pengukuran juga uji validitas konvergen juga melihat nilai Avarage Variance Extracted (AVE). Nilai AVE dapat diterima ketika nilai lebih besar dari 0,50. Nilai AVE 0,50 dan lebih tinggi, menunjukkan tingkat yang cukup untuk validitas konvergen, yang berarti bahwa variabel laten menjelaskan lebih dari setengah dari keragaman indikator. Selanjutnya, Sementara itu, tingkat konsistensi pengukuran (reliablitas) diuji dengan composite realibility. Reliabilitas tinggi (nilai $>0,6$ ) menunjukan bahwa indikator-indikator mempunyai konsistensi tinggi dalam mengukur variabel latennya. Untuk menguji inner model dilakukan dengan melihat nilai $\mathrm{R}^{2}$ pada konstruk dependen.

Berdasarkan teori dan temuan dari penelitian terdahulu, penelitian ini mengkombinasikan berbagai variabel. Berikut ditampilkan model SEM dalam penelitian ini yang memiliki 14 hipotesis dalam Gambar 1. 


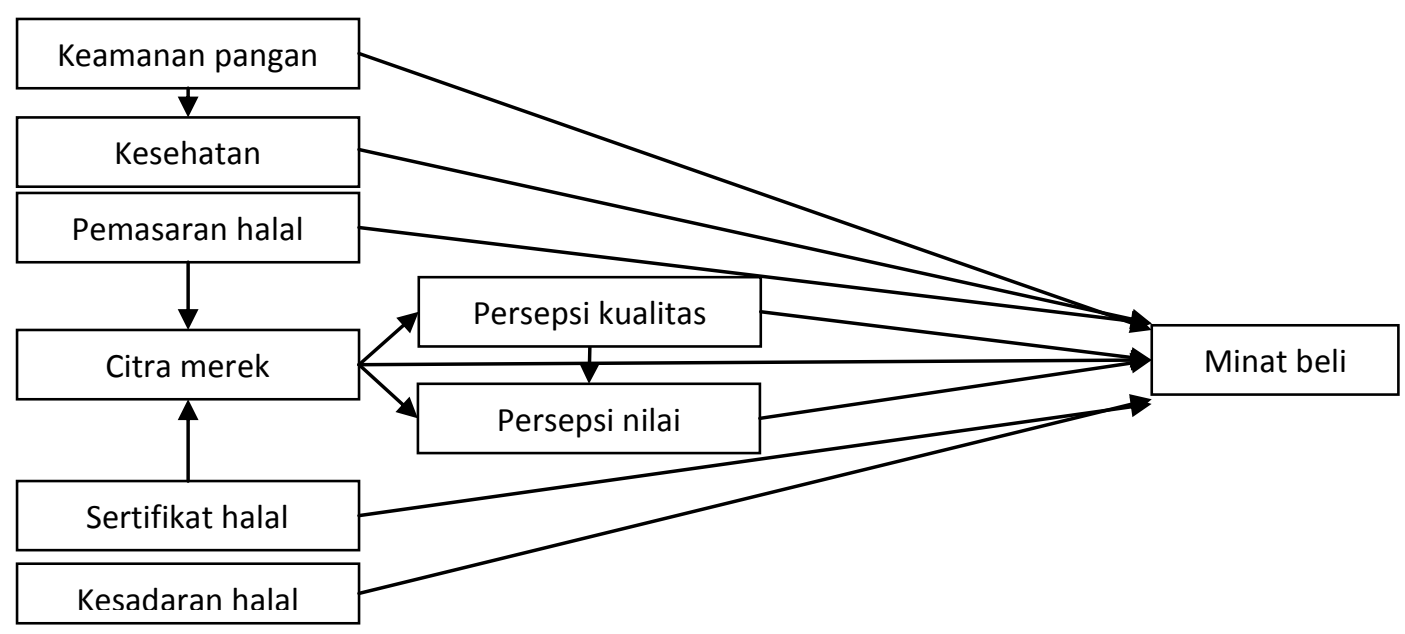

Gambar 1. Model Penelitian

Hipotesis yang dikembangkan dalam penelitian ini adalah sebagai berikut:

H1 : Citra merek berpengaruh terhadap persepsi kualitas.

$\mathrm{H} 2$ : Citra merek berpengaruh terhadap persepsi nilai.

H3 : Citra merek berpengaruh terhadap minat beli.

H4 : Keamanan pangan berpengaruh positif terhadap kesehatan.

H5 : Keamanan pangan berpengaruh terhadap minat beli.

H6 : Kesadaran halal berpengaruh terhadap minat beli.

H7 : Sertifikat halal berpengaruh terhadap citra merek.

H8 : Sertifikat halal berpengaruh terhadap minat beli.

H9 : Pemasaran halal berpengaruh terhadap citra merek.

H10 : Pemasaran halal berpengaruh terhadap minat beli.

H11 : Kesehatan berpengaruh terhadap minat beli.

H12 : Persepsi kualitas berpengaruh terhadap persepsi nilai.

H13 : Persepsi kualitas berpengaruh terhadap minat beli.

H14 : Persepsi nilai berpengaruh terhadap minat beli

\section{Hasil dan Pembahasan}

\section{III.1 Analisis Model Pengukuran}

Nilai AVE dan composite realibility secara lengkap pada Tabel 1.

Tabel 1 Nilai Composite Reliability dan Avarage Variance Extracted

\begin{tabular}{lcc}
\hline & Composite Reliability & $\begin{array}{c}\text { Average Variance } \\
\text { Extracted (AVE) }\end{array}$ \\
\hline Citra merek & 0,858 & 0,668 \\
Keamanan pangan & 0,874 & 0,636 \\
Kesadaran halal & 0,889 & 0,671 \\
Sertifikat halal & 0,927 & 0,810 \\
Pemasaran halal & 0,775 & 0,634 \\
Kesehatan & 0,906 & 0,828 \\
Persepsi kualitas & 0,884 & 0,793 \\
Persepsi nilai & 0,784 & 0,547 \\
Minat beli & 0,875 & 0,638 \\
\hline
\end{tabular}


Berdasarkan Tabel 1 dapat diketahui bahwa semua variabel laten dalam penelitian ini memiliki nilai composite realibility di atas 0.6 dan nilai AVE di atas 0,5 sehinga dapat dinyatakan bahwa variabel-variabel yang digunakan reliabel. Hal ini berarti berarti bahwa indikator-indikator yang digunakan dalam penelitian memiliki konsistensi yang baik dalam mengukur variabel latennya.

Variabel laten minat beli dapat dijelaskan oleh kesehatan, pemasaran halal, kesadaran halal dan persepsi nilai secara bersama sebesar $32,75 \%$, sedangkan sisanya tidak dijelaskan oleh variabel lain yang tidak diteliti dalam model penelitian ini. Nilai $\mathrm{R}^{2}$ variabel laten persepsi nilai sebesar 0,4938 , yang artinya variabel laten persepsi nilai yang dapat dijelaskan oleh variabel citra merek dan persepsi kualitassebesar $49,38 \%$ sedangkan sisanya tidak dijelaskan oleh variabel lain yang tidak diteliti dalam model penelitian ini.

Variabel citra merek mampu menjelaskan variabel persepsi kualitassebesar $17,24 \%$ sedangkan sisanya tidak dijelaskan oleh variabel lain yang tidak diteliti dalam model penelitian ini. Variabel citra merek mampu dijelaskan oleh variabel sertifikat halal dan Pemasaran halal sebesar 35,07\% dan variabel kesehatan mampu dijelaskan oleh variabel keamanan pangan sebesar $10,46 \%$ sedangkan sisanya tidak dijelaskan oleh variabel lain yang tidak diteliti dalam model penelitian ini.

\section{III.2 Analisis Model Struktural}

Uji selanjutnya dilakukan analisis model struktural untuk menganalisis tingkat signifikansi dan membahas pengaruh variabel-variabel laten eksogen terhadap variabel laten endogennya. Hasil analisa model structural dengan menggunakan taraf signifikansi $5 \%$ jika nilai t-statistics > 1,96, maka hipotesis nol $(\mathrm{HO})$ ditolak. Nilai tstatistik koefisien pengaruh dari konstruk laten diperoleh dari PLS Bootstrapping. Hasil Model PLS Bootstrapping di penelitian ini disajikan pada Gambar 1.

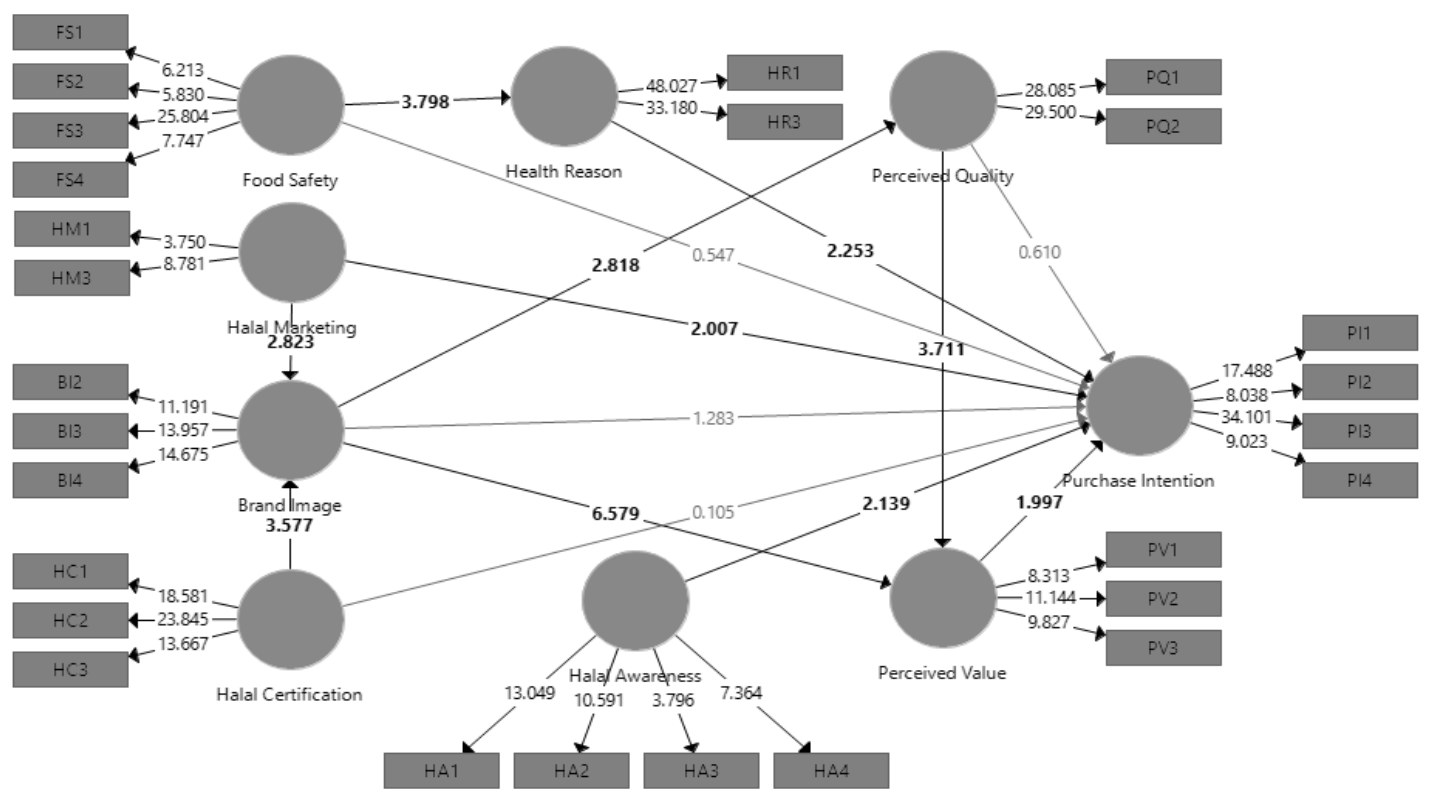

Gambar 2. Model Analisis SEM PLS Bootstraping 


\section{Pengaruh Citra merek terhadap Persepsi kualitas}

Citra merek berpengaruh positif terhadap persepsi kualitas, dengan nilai $t$ sebesar 2,818. Hasil tersebut sesuai dengan temuan Wang dan Tsai (2014) yang menunjukan bahwa citra merek memiliki pengaruh yang signifikan terhadap persepsi kualitas. Hal ini menunjukan bahwa produk makanan halal dengan merek dan yang sudah banyak diakui dan dinilai baik setelah pembelian sebagai faktor yang sangat kuat mencerminkan citra dari merek. Semakin baik citra merek suatu produk makanan halal maka persepsi konsumen akan kualitas produk juga semakin baik.

\section{Pengaruh Citra merek terhadap Persepsi nilai}

Berdasarkan penelitian yang dilakukan Wang dan Tsai (2014), citra merek memberikan pengaruh positif terhadap persepsi nilai. Pada penelitian kali ini, hasil serupa juga didapat bahwa citra merek memberikan pengaruh positif dan signifikan terhadap persepsi nilai, ditunjukan dengan nilai $t$ sebesar 6,579. Hal ini semakin meyakinkan bahwa semakin baik citra merek produk makanan halal akan meningkatkan persepsi nilai produk yang baik di mata konsumen.

\section{Pengaruh Keamanan pangan terhadap Kesehatan}

Keamanan pangan memiliki memiliki pengaruh yang positif terhadap kesehatan sebesar 0.323. Nilai t statistik yang dihasilkan yaitu 3.798, menunjukan bahwa keamanan pangan berpengaruh signifikan terhadap kesehatan, sehingga keputusan hipotesis diterima. Kemanan pangan yang direpresentasikan dengan tanggal kadaluarasa, label jaminan keamanan, konisi produk, dan asal produk menjadi indikator variabel keamanan pangan. Keamanan pangan menjadi faktor yang mendorong argument konsumen tentang kesehatan dalam memilih makanan halal. Semakin konsumen meyakini bahwa produk makanan halal yang dibeli aman dikonsumsi, konsumen akan memakin yakin bahwa konsumsi produk makanan halal itu sehat.

\section{Pengaruh Kesadaran halal terhadap Minat beli}

Hubungan antara kesadaran halal dengan minat beli menunjukan pengaruh signifikan positif dengan nilai t-statistik 2.139, sehingga keputusan hipotesis diterima. Penelitian menunjukan bahwa kesadaran masyarakat muslim untuk membeli produk makanan olahan halal tinggi. Hal ini sejalan dengan penelitian sebelumnya yang dilakukan oleh Hamdan et al (2013) dan Aziz and Chok (2013), meskipun berbeda dari hasil yang ditunjukan oleh Awan et al (2015) yang menyatakan kesadaran halal tidak berpengaruh signifikan.

\section{Pengaruh Sertifikat halal terhadap Citra merek}

Sertifikat halal memiliki mimiliki pengaruh yang signifikan dan positif terhadap citra merek dengan nilai t yaitu 3.798, sehingga keputusan hipotesis diterima. Produk makanan olahan dengan memiliki sertifikasi halal maka akan dapat meningkatkan citra merek dari produk itu sendiri. Hal ini disebabkan karena sebagian besar konsumen menilai suatu merek makan yang baik dan aman dikonsumsi adalah yang telah 
memiliki sertifikasi halal. Konsumen muslim menolak merek produk yang belum bersertifikasi halal.

\section{Pengaruh Pemasaran halal terhadap Citra merek}

Hasil olah data menunjukkan bahwa pemasaran halal memiliki pengaruh yang signifikan secara negatif terhadap pemasaran halal, dengan nilai t yaitu 2.385 dan koefisien sebesar 0.271. Temuan ini menunjukan bahwa proses pemasaran dapat mempengaruhi pencitraan masyakat akan merek suatu produk. Dengan mempertimbangkan celebrity endorsement dalam iklan dan harga yang ditawarkan dapat mempengaruhi citra positif merek.

\section{Pengaruh Pemasaran halal terhadap Minat beli}

Hasil pengujian menunjukkan bahwa pemasaran halal memiliki pengaruh yang signifikan secara negatif terhadap pemasaran halal, dengan nilai t-statistik yaitu 2,007 dan koefisien sebesar -0,226. Temuan ini tidak sesuai dengan temuan Awan et al (2015). Hal ini menunjukan bahwa orang membeli produk makanan halal tidak melihat bintang iklan yang mempromosikan dan harga yang merupakan indikator dari variabel marketing untuk mempengaruhinya dalam membeli makanan halal. Makanan halal diminati untuk dibeli karena kehalalannya bukan karena proses marketing yang ditawarkan. Sehingga penelitian ini menunjukan, bahwa pada proses pemasaran produk makanan halal, harus lebih mengutamakan mempromosikan kehalalan produk dari pada mengandalan promosi dengan bintang iklan dan harga.

\section{Pengaruh Kesehatan terhadap Minat beli}

Pada penelitian sebelumnya yang dilakukan oleh Husain et al (2016), menunjukan bahwa kesehatan bukan menjadi faktor yang mempengaruhi minat beli. Namun pada penelitian ini, hasil menunjukan bahwa variabel kesehatan menunjukan nilai yang positif dan signifikan berpengaruh pada minat beli. Hal ini menujukan bahwa orang-orang membeli makanan halal karena meyakini bahwa dengan mengkonsumsi makanan halal dapat mencekah dari penyakit, memiliki pola konsumsi yang lebih baik dan sehat. Sehingga alasan ini dapat mendorong mereka untuk melakukan pembelian produk-produk makanan olahan halal.

\section{Pengaruh Persepsi kualitas terhadap Persepsi nilai}

Berdasarkan penelitian yang dilakukan Wang dan Tsai (2014), persepsi kualitas memberikan pengaruh positif terhadap persepsi nilai. Pada penelitian kali ini, hasil serupa juga didapat bahwa persepsi kualitas memberikan pengaruh positif dan signifikan terhadap persepsi nilai, ditunjukan dengan nilai t-statistik sebesar 3,711. Hasil ini menunjukan persepsi konsumen terhadap kualitas produk makanan halal berbanding lurus dengan persepsinya terhadap nilai dari produk makanan halal tersebut. Sehingga semakin kualitas dipersepsikan baik, maka persepsi akan nilai juga akan semakin baik. 


\section{Pengaruh Persepsi nilai terhadap Minat beli}

Berdasarkan hasil pengolahan data, Persepsi nilai memberikan pengaruh positif terhadap minat beli dengan nilai t-statistik sebesar 1,997. Hasil penelitian ini didukung oleh pelitian yang dilakukan Wang dan Tsai (2014) yang menunjukan hasil serupa. Dalam hal ini, persepsi nilai yang baik dapat mendorong konsumen untuk melakukan pembelian. Nilai yang dipersepsikan adalah bahwa makanan halal merupakan favorit pembelian, harga makanan sesuai dengan nilainya, dan memiliki kuliatas yang sesuai dengan nilainya.

\section{Evaluasi Pengaruh Tidak Langsung}

Keamanan pangan, sertifikat halal, citra merek dan persepsi kualitastidak memiliki pengaruh langsung terhadap minat beli. Variabel keamanan pangan memiliki pengaruh tidak langsung terhadap minat beli melalui kesehatan. Artinya faktor keamanan pangan meningkatkan alasan kesehatan bagi konsumen dalam memilih produk makanan halal, meskipun banyak diantara konsumen tidak secara langsung memperhatikan keamanan pangan dalam mementukan pembelian.

Sertifikat halal juga memiliki pengaruh tidak langsung terhadap minat beli melalui variabel citra merek. Meskipun secara langsung sertifikasi halal tidak memberikan pengaruh terhadap minat beli konsumen, namun sertifikasi halal dapat meningkatkan citra merek produk makanan. Dengan adanya sertifikasi halal, citra merek produk makan akan semakin baik terutama dikalangan konsumen muslim.

Variabel citra merek juga memiliki pengaruh tidak langsung terhadap minat beli melalui persepsi nilai dan persepsi kualitas pengaruh tidak langsung terhadap minat beli secara berurutan sebesar -0,097 dan -0,197. Begitu juga dengan persepsi kualitas pengaruh tidak langsung terhadap minat beli pengaruh tidak langsung terhadap minat beli sebesar 0,183. Hal tersebut sesuai dengan temuan sebelumnya (Wang dan Tsai 2014) dimana meskipun citra merek tidak memiliki pengaruh langsung terhadap minat beli secara nyata, namun masih memiliki pengaruh tidak langsung terhadap minat beli.

\section{Kesimpulan}

Hasil penelitian menunjukkan bahwa variabel kesadaran halal, kesehatan, dan persepsi nilai menunjukan pengaruh yang signifikan dan positif terhadap minat beli. Hal ini menunjukan semakin tingginya kesadaran konsumen akan kehalalan produk, kesehatan dan nilai yang dipersepsikan semakin mendorong minat konsumen untuk membeli produk makanan halal. Dari ketiga variabel tersebut yang memiliki pengaruh paling tinggi adalah variabel kesehatan dengan nilai $t$ sebesar 2,253. Adapun Pemasaran halal memberikan pengaruh signifikan namun negatif menunjukan bahwa proses marketing diperlukan namun tidak perlu menonjolkan unsur duta iklan dan harga. Pemasaran halal juga memberikan pengaruh yang signifikan dan positif terhadap citra merek. Sedangkan variabel keamanan pangan, sertifikat halal, citra merek, dan persepsi kualitas tidak memiliki pengaruh langsung terhadap minat beli. Keamanan pangan memiliki pengaruh tidak langsung terhadap minat beli melalui kesehatan. Sertifikat halal memiliki pengaruh tidak langsung terhadap minat beli melalui variabel citra merek. Sedangkan, citra merek, dan persepsi kualitas memiliki pengaruh tidak langsung melalui variabel persepsi nilai terhadap minat beli, artinya 
citra merek dan persepsi kulaitas yang baik akan mendorong meningkatnya persepsi nilai dari produk, peningkatan persepsi nilai inilah yang dapat meningkatkan minat beli konsumen.

\section{Daftar Pustaka}

[BPS] Badan Pusat Statistik. 2010. Penduduk Menurut Wilayah dan Agama yang Dianut. [Internet]. [diunduh 2016 Oktober 6]. Tersedia pada: http://sp2010.bps.go.id/index.php/site/tabel?tid=321.

[BSN] Badan Standarisasi Nasional. 2014. BSN Dukung Bogor sebagai Kota Halal. [Internet]. [diunduh 2017 September 1]. Tersedia pada: http://www.bsn.go.id/main/berita/berita_det/5714\#.WbDqBMYxXDd

Ahmad MF. 2014._Antecedents of halal brand personality. Journal of Islamic Marketing Vol. 6 No. 2, 2015 pp. 209-223.

Al-Ghazali. 2007. Etika Islam Bimbigan Awal Menuju Hidayat Ilahi. Bandung (ID) : Pustaka Setia

Ambali AR. dan Bakar AN. 2013. Halāl Food And Products In Malaysia: People's Awareness And Policy Implications. IIUM Press Intellectual Discourse, 21:1 (2013) 7-32.

Apriyantono dan Anton. 2005. Makanan dan Minuman Halal. Bandung (ID): Kiblat Buku Utama.

Asyraf dan Wan Mohamad. 2013. A Comparison Of Partial Least Square Structural Equation Modeling (PLS-SEM) and Covariance Based Structural Equation Modeling (CB-SEM) for Confirmatory Factor Analysis. International Journal of Engineering Science and Innovative Technology (IJESIT) Volume 2, Issue 5, September 2013.

Aziz Y.A. and Chok N.V. 2013. The Role of Kesadaran halal, Sertifikat halal, and Marketing Components in Determining Halal Minat beli Among Non-Muslims in Malaysia: A Structural Equation Modeling Approach. Journal of International Food \& Agribusiness Marketing, 25:1-23, 2013

Borzooei M, and Asgari M. 2013. The Halal Brand Personality and Its Effect on Minat beli. Interdisciplinary Journal Of Contemporary Research In Business Vol 5, No 3 July 2013.

Burhanuddin. 2011. Hukum Perlindungan Konsumen. Malang (ID): UIN Maliki.

Cooper DR. dan Emory CW. 1997. Metode Penelitian Bisnis Jilid 1 Edisi Kelima. Jakarta (ID): Penerbit Erlangga.

Husain R, Ghani IA, Mohammad AF, and Mehad S. Current Practices among Halal Cosmetics Manufacturers in Malaysia. Journal of Statistical Modeling and Analytic Vol. 3 No. 1, 2012 pp. 46-51.

Kementrian Agama. 2015. Data Sertifikasi Halal LPPOM MUI. Kementrian Agama, Direktorat Jenderal Bimbingan Masyarakat Islam.

Latan H. 2013. Struktural Equation Modeling: Konsep dan Aplikasi menggunakan Program LISREL 8.80. bandung (ID): Penerbit Alfabeta.

Mix Editor. 2017. Kebangkitan Pasar Muslim Indonesia. [Majalah]. Mix: Marketing \& Communication 06/XIV 20 Juni 2017 - 18 Juli 2017. 
260 | Nurhasanah S, Munandar JM, Syamsun M - Faktor-Faktor yang Mempengaruhi Minat Beli Produk

Mulyono, Dedi. 2016. Pengaruh Media Sosial Terhadap Keputusan Memberikan Donasi pada Rumah Zakat [Tesis]. Bogor (ID): Institut Pertanian Bogor.

Qaradhawi Y. 2013. Halal dan Haram. Bandung (ID): Penerbit Jabal.

Rajagopal S. 2011. Sertifikat halal: Implication for Marketers in UAE. Journal of Islamic Marketing Vol. 2 No. 2, 2011

Syahruddin. 2014. Potensi Kemajuan Umat Melalui Produk Halal. [Internet]. Tersedia http://majalahgontor.net/potensi-kemajuan-umat-melalui-produk-halal/.27 Agustus 2014; Diunduh 4 Januari 2015.

Wang YH. and Tsai CF. 2014. The Relationship Between Citra merek And Minat beli: Evidence From Award Winning Mutual Funds. The International Journal of Business and Finance Research Vol.8 No.2 2014. 